\title{
Application of People-oriented thought in Ideological and Political Education Work for College Students
}

\author{
Tu Liyan \\ Inner Mongolia University for the Nationalities, Tongliao, Inner Mongolia, 028000, China;
}

Keywords: People-oriented; College student; Ideological and political education

\begin{abstract}
Along with the speeding up of China's education system reform and social transformation, the goal and content of College Students' Ideological and political education have undergone major changes, traditional methods of Ideological and political education is becoming increasingly unable to meet the actual needs, which not only hinders the development of students independent and individual, also limit of the students' creative play. The people-oriented thought into the ideological and political education of college students, expounds the necessity and importance of peopleoriented ideological and political education, and put forward the suggestions for the improvement and innovation of methods of Ideological and political education for college students.
\end{abstract}

\section{Connotation of people-oriented thought}

People-oriented, is take the human as the center, the people as the fundamental, all for the people, everything depends on people, its essence is in the fundamental interests of the people as the fundamental, to promote people's all-round development, concrete content mainly includes the following aspects, the first fully affirmed the subject status of people, namely "all rely on the people, all for the people"; secondly to fully respect the people of their own [1]. "People-oriented" the people as the main body of the people of the world and society, emphasizing the urgent demand of the people in terms of concern, care and understanding, who comes to display of human nature, are worthy of understanding and respect. Therefore, everyone should respect themselves, but also respect for others [2]. Third, the people-oriented thought clears the value orientation of people. Man is the subject of creating value and social significance. As the individual of social life, the value and significance of life are the value of creating social development, which is to meet the needs of others and realize their own significance.

\section{The problems of Ideological and political education for college students at present}

At present, the ideological and political education methods of college students have achieved some achievements, and it has promoted the effective development of Ideological and political education. However, along with the change and development of the times, its theoretical defects and the shortcomings of the application are increasingly apparent [3][4]. Because both from the perspective of the methods of College Ideological and political education implementation level and research level, or from the educators and the educated is the main viewing, different degrees exist many problems and deficiencies, need to be further studied and perfected.

Educators lack the idea of "people-oriented". Educators in the methods of College Ideological and political education in the process of applying, of all sorts of new contradictions and new problems appear is not enough attention, especially failed to deeply concerned about college students' Ideological and psychological confusion, so that the ideological and political education cannot meet the actual needs of the students. Many educators fail to mobilize the initiative of the students because of the lack of the people-oriented concept of education [5]. The ideological and political education methods of college students are mostly to persuade education and unconditional obedience, but not from the perspective of human nature to care for the development of the educated. Pay attention to the theory, neglect the students' main body status, failed to function as a role model. 
The traditional education method and the modern education method cannot combine organically. First, some educators re education and neglect of modern education, while some of the educators focus on modern education and the neglect of traditional education, these two phenomena coexist. Both the traditional education method and the modern education method have their own advantages and disadvantages, they should complement each other. There are two kinds of extreme tendencies in the course of the ideological and political education in the current college students: one is the conventional method, the use of the modern method is not enough. Two is the excessive application of modern methods, so that the dominant positions of the traditional methods are increasingly marginalized. In the current ideological and political education of college students, there are some advantages of modern ideological and political education. But needs to be noted is that to teach college students and instill certain ideological theory and moral standard is the essential meaning of the ideological and political education of college students. The purpose is all aspects of training and improving the students' quality, become a useful person for the needs of the society.

Secondly, the college students blindly reject the traditional education method. Affected by many aspects, the current social environment, contemporary college students exhibit unique thinking and behavior characteristics, enhance their independent consciousness and independent consciousness, active thinking, willing to accept new things. But their outlook on life, values is not perfect, in the choice of methods of Ideological and political education in college students, often exhibit blindly reject traditional, advocating modern that as long as the traditional should be abandoned, modern should advocate, as long as the form pattern, do not stand out, only to see a process, not the outcome. That some educators only from students one-sided needs, in the choice of teaching methods and the use of excessive use of modern teaching methods, one-sided emphasis on novel and formal, and blind to the exclusion of the traditional education method, thus dilute and weaken the ideological and political education of the scientific method.

\section{On the necessity and importance of guiding college students in the ideological and Political Education}

The need for building a harmonious socialist society. The eighteenth session of the National People's Congress proposed to form a prosperity, democracy, civilization, harmony, freedom, equality, justice and the rule of law and patriotism, dedication, integrity, friendly socialist core value view in the society. And the core value of socialism is the key to building a socialist harmonious society, college students are the main force of the construction. Therefore, strengthening the ideological and political education in Colleges and universities is very necessary. Harmonious Society for high school students provide the all-round development of the social background and the realistic environment, also a harmonious society also requires the ideological and political education of college students can mediate the college students psychological perplexity, difficulties in life and in society with others, interpersonal exchanges and communication.

Construction of harmonious campus needs. The harmonious development between university teachers and college students is the concentrated expression and essence of the harmonious society in the campus. In the construction of harmonious campus in the process, not only need to colleges and universities in the material culture in strengthening the management measures of implementation, but also need the strengthening of "people oriented" Ideological and political education work in Colleges and universities. So in the implementation of the educational activities, especially in the ideological and political education activities, more need to adhere to the "peopleoriented" principle of education, can reflect the comprehensive ability of the ideological and political education in Colleges and universities in the construction of the campus atmosphere and style.

To grasp the law of Ideological and political education in Colleges and Universities. Any form of Ideological and political education in Colleges and universities cannot be separated from the objective law, and any form of Ideological and political reform in Colleges and universities must be based on the ideological and political education law foundation. Therefore, in the 
ideological and political education in Colleges and universities must follow the law of Ideological and political education, so as to promote the development of Ideological and political education in Colleges and universities, and eventually accepted and recognized by the educators. In the people oriented Ideological and political education and the educated is the subject of educational activities, in this process due to the equal status of the educators and the educated and communicate with each other, and jointly promote the harmonious development of Ideological and political education in Colleges and universities.

Is conducive to the full development of College Students. College students as the core strength of social development, although still in the study stage, but the potential of the employment pressure has slowly infiltrated all aspects of college students learning and life. In the increasingly fierce competition in employment, the improvement of college student's subject quality and the comprehensive development of the comprehensive knowledge have become the inevitable requirement for college students to adapt to the rapid development of society. Therefore, strengthening the ideological and political education of college students is conducive to improving college students' adaptation to social development and the comprehensive quality of the times, which is conducive to promoting the comprehensive development of college students.

\section{Improve the people-oriented ideological and political education measures}

\section{Establish the scientific ideological and political education idea.}

Establish the concept of respecting students

Respect education subject in the college students is required to respect every college student's right, personality and their thoughts, and students get along equally, rather than for superior sense; in the teaching process to actively promote students participation, enhance the learning of college students sense of presence, and to guide and inspire students in teaching activities put forward their own ideas, give full play to the student's creative and improve the ability of independent thinking. The ideological and political education in Colleges and universities should be filled with the education of caring for the students, not the cold education of the doctrine.

Establish the concept of service students

In the ideological and political education in Colleges and universities to implement peopleoriented should further establish the concept of service students, making the students become the main interests of the subject of education. First, in the ideological and political education in various teaching links, the implementation of the concept of service students, and enhance the awareness of service for college students. Second, maintain legitimate rights and interests of students and reasonable requirements, conditions should be created to try to meet students' reasonable needs will meet needs of students and student services combined, the ideological and political education really come into the heart of students.

The content of education is the basic of the contemporary college students' needs

The basic content of Ideological and political education should be the moral education, psychological education and legal education for college students. The purpose of moral education is to lead students to establish the correct moral values and good behavior standards, which can promote the contemporary college students to practice the socialist concept of honor and disgrace.. Moral education is the most basic and important task in Ideological and political education.. Psychological education of Ideological and political education is to make students to correctly understand and evaluate their own, can correct understanding and evaluation of today's society, to correct their unhealthy psychological status, cultivate the spirit of college students are positive. Law education is to make college students have basic legal knowledge and legal concepts, and cultivate college students' awareness of safeguarding rights and fulfilling their obligations.

Change the teaching mode of Ideological and political ideas, and promote the students' main position. Students self-learning ability, has been an important goal of politics teaching reform. However, a long ideological and political theory teaching followed the traditional model, without considering the actual needs of student growth and talent, both in the curriculum, or teaching content, methods and means have to be updated. Adhere to the "people-oriented" teaching 
philosophy is to take into account students' training and development of all abilities. Not only enable students to master the Marxist theory of knowledge, and more importantly taught to follow the student entrepreneurs thinking needs, close to the student's actual thinking ability of students to apply Marxist theory and consciously study new situations, solve new problems, explore new methods.

Focus on building an equal and harmonious teacher-student relationship. The harmonious teacher-student relationship is the key to realize the education idea of the ideological education, and it is also the main way of realizing the effect of the ideological and political education of the people-oriented University. The traditional education mode, education in the whole teaching process is often claim by the respect of the educated, educated to absolute obedience to educators, the educated for the education of discontent are often not reasonable to talk, only through the education of their own inner world to digest. All, only in the process of meeting the students' demands and development needs, the mutual understanding and trust between the educators and the educated two can be stabilized. In a word, in the educators and the educated in the education process and communicate with each other, to fully reflect the students' subjectivity, autonomy and creativity and respect the students' ideas, adhere to the student oriented establish equality, mutual aid and harmonious relationship between teachers and students.

Strengthen the quality of Ideological and political education troop. The team of College Students' Ideological and political education is the subject of Ideological and political education work, is mainly responsible for the work of College Students' Ideological and political education, guidance, organization and implementation, is to strengthen and improve ideological and political education of college students and an important guarantee for the essence request. Contingent of Ideological and political education of colleges and universities is directly related to the quality of the ideological and political education in Colleges and universities can effectively carried out, can maximize the college students comprehensive quality. Therefore, it is necessary to strengthen the ideological and political education troop quality construction.

\section{References}

[1] Tom van Weert. Higher Education: Learning in Real life [J] . IFIP International Federation for Information Processing. 2005.

[2] Marxism, Postmodernism, and Beyond. A Critical Analysis of David Harvey of Contemporary Culture” Current Perspectives in Social Theory, 2004

[3] Clark A. Miller, Interrogating the Civic Epistemology of American Democracy: Stability and Instability in the 2000 US Presidential Ehction, Social Studies of Science, 2004, 34(4): 501-530.

[4] Wang Chang. Research on College Students' Ideological and Political Education Methods Under the Guidance of the People-Oriented Thinking[C], Liaoning University, 2014.

[5] Stephen De Wize, The Family and Political Justice: The Case for Political Liberalisms, Journal of Ethics, 2000, 4(3):257-281. 